\title{
Simultaneous Invention and Rent Seeking in the Development of Telephony
}

\author{
Samantha J. Wineke ${ }^{1}$, Steven B. Caudill ${ }^{1} \&$ Franklin G. Mixon, Jr. ${ }^{2}$ \\ ${ }^{1}$ Department of Economics, Rhodes College, Memphis, TN 38112, USA \\ ${ }^{2}$ Center for Economic Education, Columbus State University, Columbus, GA 31907, USA \\ Correspondence: Franklin G. Mixon, Jr., Center for Economic Education, D. Abbott Turner College of Business, \\ Columbus State University, 4225 University Avenue, Columbus, GA, 31907, USA. Tel: 1-706-507-8052. E-mail: \\ mixon_franklin@columbusstate.edu
}

Received: March 25, 2014 Accepted: June 20, 2014 Online Published: August 25, 2014

doi:10.5539/jpl.v7n3p1 URL: http://dx.doi.org/10.5539/jpl.v7n3p1

\begin{abstract}
The concept of "simultaneous invention" describes the idea that inventions are often the result of market changes or incremental progress or innovation, rather than an enlightened moment bestowed upon a single individual. Historical evidence indicates that the development of telephony provides a compelling example of this concept. This study re-examines the development of telephony, also providing a public choice perspective on how Alexander Graham Bell was able to use the U.S. patent system to his advantage. As a result of Bell's prowess in this regard, other important figures, namely Amos Dolbear and Elisha Gray, who were also involved in the development of telephony, are relatively unknown today.
\end{abstract}

Keywords: simultaneous invention, patent races, development of telephony, legal monopoly

\section{Introduction}

Few, if any, "new" inventions occur without the benefit of preceding inventions. Each invention is an extension of the work of a previous inventor, often a result of building and improving upon history's talents. Lemley (2012) discusses the concept of "simultaneous invention," pointing out that inventions are often the result of market changes or incremental progress or innovation, rather than an enlightened moment bestowed upon a single individual. According to Lemley (2012: 709), "[s]urveys of hundreds of significant new technologies show that almost all of them are invented simultaneously by two or more teams working independently of each other ... [thus, i]nvention appears in significant part to be a social, not an individual, phenomenon." The development of telephony followed what Lemley refers to as simultaneous invention. While recognition associated with the development of the telephone is typically given to Alexander Graham Bell, many historical documents show that he was not the sole pioneer in telephony, as other important figures who are relatively unknown today, such as Amos Dolbear and Elisha Gray, were also involved in providing telecommunications advances. It was only with the assistance of his legal team that Bell developed what was then a monopoly in telephony, and that today is a widely recognizable telephone service provider - American Telephone \& Telegraph Company (AT\&T). This study fills a gap in our knowledge of the development of telephony by (1) identifying telephony as an example of simultaneous invention, thus providing, in a single study, an historical account of events surrounding the transmission of speech, and (2) describing how the concept of rent seeking was utilized by Bell and his attorneys in securing a monopoly in the provision of telecommunications, thus providing a public choice perspective on how Bell was able to use the U.S. patent system to his advantage. Given the chronology of events, these concepts - simultaneous invention and rent seeking - appear in order in the section below.

\section{Simultaneous Invention in the Telephone Patent Race}

Contrary to what many children are taught in school, the Bell Telephone Company provides a classic example of simultaneous invention. The concept of the telephone could not have been conceived without the efforts of innovators who preceded the development of telephony, such as (1) Alessandro Volta, the inventor of batteries, (2) Hans Christian Oersted, who studied the effect of a current of electricity on magnets, and (3) Joseph Henry, the father of electromagnets. The history of telephony began hundreds of years before the telephone was put into use, when, in 1558, well before any patent law was established, Giambattista della Porta described a 
"sympathetic telegraph" (Dolbear, 1963: 116).

\subsection{Setting the Stage: Patent and Antitrust Law in the U.S.}

In 1788 the United States formally adopted patent law within the U.S. Constitution, wherein Article I, Section 8, describes exclusive rights given to inventors in order to "promote the Progress of Science and [the] useful Arts." It was not until 1836, however, that the Patent and Trademark Office was created, allowing for more careful observation of patent laws (Durham, 2004). The main purpose of the development of patent laws was to ensure that sole inventors were given, in the form of limited monopoly, sufficient incentives to develop new products, thus leading to more inventions than would have occurred in the absence of a limited monopoly (Devlin, 2009). Antitrust law had also begun to develop in the 1800 s, when monopolies became widespread. While antitrust and patent laws appear to oppose one another, they were intended to create a balance between innovation and competition. As Letwin (1965) indicates, developing a legal structure that would create such a balance proved to be difficult.

While antitrust laws were still being developed in the U.S., the idea of a speaking telephone continued to form and spread throughout both the U.S. and Europe. In 1837, Charles Page invented a telephone that transmitted sounds through a tuning fork. Between 1849 and 1851, several individuals (e.g., Meucci, Petrina, Cushman, and Farrar) claimed invention of sound-transmitting instruments, including some that were capable of transmitting musical tones electrically. Three years later, in 1854, Charles Bourseul described an invention that transmitted speech, while in 1860, Sir Charles Wheatstone was granted a British patent for his invention of "musical pipes for free tongues [that] are acted on by wind" (Dolbear, 1963: 117). More widely-known inventors in this field include Johann Phillip Reis and Hermann von Helmholtz. In 1860, Reis used Page's aforementioned receiver and magnetic induction to create an instrument that transmitted speech electrically. Two years later, in 1862, von Helmholtz authored a book that explained how electricity could be used to transmit speech (Dolbear, 1963).

\subsection{The Race is Joined: Dolbear, Gray and Bell Compete for a Telephone Patent}

It was in 1865 that Amos Dolbear considered the idea of developing a telegraph that replaced batteries with permanent magnets. The following year, S.N. Yeates created a telephone, but its faint sounds proved unfit for practical use (Dolbear, 1963). In 1867, famous inventor Elisha Gray began to conceive the idea of a harmonic telegraph, but decided to concentrate on tasks he considered more important (Gray, 1878). The most well-known inventor of the telephone, Bell, claims his revelation came in 1870, when he thought of creating a telegraph to communicate messages simultaneously over a single circuit (Dolbear, 1963). Soon after, the telephone became the object of a "patent race." Rather than inventions taking place sporadically every few years, inventors were taking rapid strides in the development of the telephone, with patent applications being filed every time progress was made in the endeavor. Lemley (2012) argues that one reason the government allowed so many patents to be issued - about 200,000 per year - is that it promoted a patent race, which involves competition, as several inventors try to speed up the process of invention in order to gain exclusive rights to the ultimate product. Many of the inventions that are regaled throughout history, such as the steam engine, cotton gin, telegraph, sewing machine, light bulb, automobile, and airplane, involved simultaneous invention, yet those who won the individual patent races also garnered most, if not all, of the fame (Lemley, 2012). The development of telephony followed a similar path.

The competitors that are the main focus of this study are Bell, Gray, and Dolbear. The latter was, in 1873, experimenting with sound, electricity, and permanent magnets in an effort to convert sound vibrations into electricity. Dolbear in fact wrote specifically about a "vibratory current in a closed circuit originated by sound vibrations" (Dolbear, 1879). In April of 1874, Gray filed his first patent application for a series of transmitters that tuned to different pitches, and in May of 1874 he demonstrated his instruments to the Western Union Telegraph Company (Dolbear, 1963). ${ }^{1}$ In the summer of 1874, Bell explained his idea of a harmonic-multiple telegraph to two men: Gardiner Greene Hubbard, a lawyer, and Thomas Sandars (Dolbear, 1963). They formed an agreement in which Hubbard and Sanders would fund Bell, and the three would divide equally any profits from Bell's inventions. Bell was given the aid of a student, Thomas Watson, who provided electrical knowledge, while his benefactors funded a small workshop wherein Bell could experiment (Dolbear, 1963).

Bell needed Watson's assistance in getting his harmonic telegraph invention into shape, which he believed would send six messages simultaneously over wire (Watson, 1915). Watson took charge of the project. Bell believed that the missing piece required to finish this product was a current that undulated in waves - more simply put, he needed sound vibrations. It was at the same time that he developed the idea of a talking telegraph. As Bell described, "[i]f I could make a current of electricity vary in its intensity, precisely as the air varies in density during the production of sound, I should be able to transmit speech telegraphically (Watson, 1915: 
1,506)." He did not pursue this idea immediately, though, and continued to work on his harmonic telegraph. By October of 1874, Bell filed a patent for his harmonic-multiple telegraph. In what appears to be a classic case of simultaneous invention, Bell was informed by the patent office that Gray had filed an interfering patent; receiving this news, Bell continued to make alterations to his invention (Dolbear, 1963).

\subsection{The Race is Won: A Public Choice Perspective of Bell's Telephone Patent}

On April 6, 1875, Bell obtained a patent for "A Method of Multiple Harmonic Telegraphy," which was "a form of transmitting instrument which could be utilized on telegraph lines and transmit two or more telegraphic signals simultaneously across wires (Dolbear, 1963: 125)." Within this patent, Bell was using an electro-magnet, rather than the permanent magnet with which Dolbear experimented. This became the famous patent in which Bell was given credit for the invention of the telephone. It must be emphasized that within this patent, nothing was mentioned about the transmission of electrical speech, and Bell had yet to capture articulate words using the machine. It was not until early June of 1875 that an accident took place that changed Bell's life. He was working on his harmonic telegraph in one room tuning receivers while Watson was in another (Watson, 1915). Watson snapped the steel reed of an instrument which was connected to the same circuit, while Bell was cursing at the instrument in the other room in frustration. Bell then excitedly ran into the other room and announced to Watson that he had heard the first real sound to be transmitted electrically, realizing that it should be able to transmit speech as well. That night, he gave Watson directions on how to construct the first speaking telephone (Watson, 1915).

It was at this point, nearing the beginning of 1876, that the story of the development of telephony connects with the public choice concept of rent seeking, as described in Tullock's (1967) seminal study on the welfare cost of tariffs, monopoly and theft, which shed new light on the resource costs associated with efforts to secure monopoly in various industries. Tullock's analysis was later supplemented by Krueger (1974) and Posner (1975), with the former coining the term "rent seeking" to describe lobbying activity as an avenue for firms to seek political favor that results in some type of barrier to entry, such as a patent, that protects incumbent producers from potential competition, as in the development of telephony. In January of 1876, Bell's lawyers took his new patent, which provided improvements in telegraphy, to the patent office. They persuaded officials there to use "prompt and preferential treatment (Dolbear, 1963: 127)." On February 14, 1876, Bell and Gray were forced to compete head to head against each other. On this day, Bell's patent had been filed, as well as Gray's caveat for an electric speaking telephone. Gray submitted a patent on the "art of transmitting vocal sounds or conversations telegraphically through an electric circuit (Gray, 1878: 79)." Both were told on February 19, 1876, that there would be a 90-day period during which Bell's patent would be suspended and Gray would have an opportunity to file another application (Dolbear, 1963). Bell's attorneys argued, however, that Bell's patent had been filed earlier in the day on the February 14, 1876. Hearing this, the patent office revised its statement, and lifted the suspension on Bell's patent (Dolbear, 1963). Bell's lawyers took the liberty of informing Gray, who did not understand the circumstances. Gray remained under the impression that he still had 90 days to file his own patent (Dolbear, 1963).

On March 7, 1876, Bell was given his patent on "Improvements in Telegraphy," and Gray had no opportunity to defend his own invention. Gray noticed that Bell's patent was nearly identical to the caveat that he had applied for on February 14, 1876 (Dolbear, 1963). Furthermore, Bell had never spoken of using a liquid transmitter until February 14, 1876, and he could not get his invention to work properly until March of 1876, a month after his patent had been filed (Dolbear, 1963). Thus, skepticism arose, as some believed that Bell's attorneys were dealing unfairly within the patent business. It was rumored that they had access to the patent office officials through an "underground railroad" (Dolbear, 1963: 129). On March 10, 1876, the telephone Bell had created transmitted its first, famous sentence: "Watson, come here, I want you (Watson, 1915: 1,510)." However, during an exhibition in May of 1876 at the American Academy of Arts and Sciences at Boston, Bell's invention could only produce inaudible sounds (Dolbear, 1963).

In the fall of 1876, Dolbear met Percival D. Richards, who offered to market his inventions. Dolbear already had a telephone prepared, which used a permanent magnet and required only a few slight improvements before marketing (Dolbear, 1963). He was ignorant to the formalities of patent law, however, and had no idea that he was facing intense competition. Dolbear wanted to perfect his telephone so that it was of the utmost ability by the time he applied for a patent. Thus, instead of rushing to the patent office, he brought his telephone to a machine shop in order to have the rods re-magnetized (Dolbear, 1963). Unfortunately, Dolbear was unaware that this was the same shop in which Bell, his main competitor, performed all of his experiments. Hubbard contacted Richards to tell him that this permanent magnet telephone had already been patented by Bell (Dolbear, 1963). Having been friends with Bell, Richards believed that Hubbard was telling the truth and did not verify the claim. 
When Richards proposed a joint patent between the two inventors, Hubbard refused. At this point, Dolbear and Richards discontinued (some say foolishly) their attempt to obtain a patent (Dolbear, 1963).

Parallel to his patent battle the year before with Gray, Bell had never mentioned using a permanent magnet in his telephone before obtaining a patent for it on January 30, 1877. This was only four days after he had filed, and conveniently right after Dolbear had sent his invention to the machine shop. Within this patent, Bell had also spoken of his discovery of "pulsatory currents from magnets acting upon a circuit," a subject about which Dolbear had discussed in a published paper in 1873 (Dolbear, 1963: 139). It was then that Dolbear became aware that he had perhaps gifted Bell the telephone invention, which included his original idea of a permanent magnet and metallic diaphragm (Warner, 1994).

Upon this realization, Dolbear wrote Bell a letter seeking clarification on the matter. When Bell did not reply, Dolbear wanted to file a lawsuit but his attorney persuaded him that a lawsuit would be both lengthy and costly. Bell ultimately replied to Dolbear with a letter claiming that he had no previous knowledge of Dolbear's invention, and he invited Dolbear to visit him in person to discuss matters further (Warner, 1994). When Dolbear arrived at Bell's home, he was asked if it was okay if a "friend" were present (Dolbear, 1963: 141). Bell's "friend" was actually his attorney, Hubbard. Dolbear explained his inventions to Bell and Hubbard, but received no reciprocation from the two concerning Bell's inventions. Dolbear claimed that Bell did, however, state that, "[i]f Dolbear had applied for a patent on the receiver during the fall of 1876 he would have been ahead of Bell," although later, under oath, both Bell and Hubbard denied such a statement on Bell's part (Warner, 1994: 11). Moreover, Bell and Hubbard testified to the opposite - that Dolbear admitted to Bell that Bell had invented the telephone first (Dolbear, 1963). ${ }^{2}$

Though he was facing what he believed to be unfair circumstances, Dolbear remained confident that he had an invention that was more useful than Bell's and that would provide greater benefit to the public. To gain funds for his experiments, Dolbear made an agreement with the Western Union Telegraph Company on December 6, 1877 , for the provision of funding. ${ }^{3}$ Soon after, Western Union was investigated by the Bell Telephone Company for infringement, and the former wanted to cancel their contract with Dolbear and buy his inventions. Dolbear asked for $\$ 10,000$, and Western Union agreed (Dolbear, 1963). Later, Dolbear discovered that Western Union was willing to pay him up to $\$ 100,000$ for his inventions (Warner, 1994). ${ }^{4}$ This case against Western Union would later be referred to in history as the "Dowd" case, and it would be the precedent for the monopoly that the Bell Company would build. As Dolbear (1963: 152) concludes, "Bell and his associates were the promoters of the invention Bell claimed as his own, and their successors in the Bell Company were the ones who by their relentless legal suits were able to destroy all other telephone usage and to build up one of the greatest industries in the world."

As Western Union prepared for the case, William H. Forbes approached Hubbard and Sandars seeking financial backing in return for control of the company. ${ }^{5}$ Within three months of working in Western Union, he was elected president. Now under his control, the Bell Telephone Company merged with the New England Company to create the National Bell Telephone Company. Western Union still provided intense competition, though, and National Bell saw them as a major threat (Dolbear, 1963). The two companies avoided a court case and instead agreed that National Bell Telephone Company would pay Western Union a nominal fee, and in return receive rights to all of Western Union's patents, including those of Dolbear and Gray. In the future, Western Union would discontinue their work on telephones and continue only with telegraphs (Dolbear, 1963). Because of his earlier settlement with Western Union, Dolbear gained no benefit from the agreement. On March 17, 1880, National Bell Telephone Company officially acquired the assets and liabilities of Western Union. The Bell monopoly was quickly gaining force as it acquired its competitors (Dolbear, 1963).

Judge John Lowell of Massachusetts filed a decree on April 14, 1881, giving Bell exclusive rights to the electrically speaking telephone. Bell's attorneys won this case by stating that his patent consisted of "any device that transmitted speech by electricity (Warner, 1994: 12)." Rather than the patent pertaining to the specific telephone Bell had allegedly created, Bell was now stating that he had a right to all electric transmission of speech. This claim is seen to be extremely influential to history given that without the phrases "speaking telephone" and "articulate speech" in the Bell patent, "[n]owhere could the judge reasonably discover that the patent had to do with the transmission of speech, i.e. a telephone (Warner, 1994: 12)."

American Bell Telephone Company was involved in 600 cases regarding Bell's telephone patent (Langdon, 1933). In each case, Bell won due to the original "Dowd" decision. ${ }^{6}$ One of the 600 cases began on October 20 , 1880, when American Bell Telephone Company sued Dolbear for infringement (Langdon, 1933). Dolbear had continued to work on the telephone after his agreement with Western Union ended, and he was praised by the 
editor of Scientific American as having developed the best telephone. In addition, the magazine stated that if he had been knowledgeable of patent laws, Dolbear may hold fame as the inventor (Warner, 1994). Dolbear's most recent phone used static electricity, which is very different from the dynamic electricity that Bell's telephone used. He was the first to apply static electricity to an invention in general, and clearly the first to use it in a telephone. Dolbear's invention was superior in that it transmitted speech over longer distances, did not have problems with induction, produced clearer speech, and was completely original (Dolbear, 1963).

The State of Massachusetts granted Dolbear a charter on December 10, 1879, for the development of The Dolbear Electric Telephone Company. On May 31, 1880, Dolbear filed for a patent for this invention, but was rejected, with the Commissioner of Patents stating that "it would not work as it was contrary to science (Dolbear, 1963: 164)." After later proving his invention's abilities to the Commissioner, the patent was granted to Dolbear on April 5, 1881. He continued to improve upon his new telephone, and was granted another patent on April 26, 1881 (Dolbear, 1963). ${ }^{7}$

It seemed impossible that Dolbear could lose this court case against Bell. Judge Gray stated that "t]here can be no patent for a mere principal," but still that Bell was "not restricted to the particular form of mechanism or apparatus by which he carries out that process (Dolbear, 1963: 171)." This did not seem logical to Dolbear's attorney, who argued that it is impossible to patent the basic idea of transmitting speech by wire. Dolbear's defense argued that this idea had already been public knowledge, citing Reis' and other inventions that preceded those of Bell, adding that such a broad process cannot be patented, but the mechanism specified within the patent could (Dolbear, 1963). ${ }^{8}$

On the date of August 25, 1883, Judge John Lowell decided in Bell's favor once again, forcing Dolbear to discontinue his work and give all profits to American Bell Telephone Company. The judge stated that Reis' invention did not pave way for Bell to create the telephone, but still believed that Bell had paved the way for Dolbear to invent his own version of the technology. Bell had, once again, "exclusive right to manufacture and operate any form of the telephone (Dolbear, 1963: 172)." This decision brought about a rise of anger among inventors. They believed that this court case went against the patent system, and saw that the courts were paving the way for American Bell Telephone Company to rise as a monopoly. Even James Lightfoot, a patent examiner, stated, "[t]he court decision rendered in the case of the American Bell Telephone Company against Amos E. Dolbear, et al., was the most incredible and unjust decision that the patent office has ever witnessed (Dolbear, 1963: 173)."

Patent laws require that each patent abide by a multitude of standards. As noted earlier, Bell patented an "abstract idea (Durham, 2004: 24)." While the actual telephone that Bell drew within his patent would have been a valid invention, the whole concept of transmitting speech described previously appears to have been too broad to patent. Patent applications require that potential inventions be described in a detailed manner such that experts in that particular field are able to recreate them (Durham, 2004). Moreover, in order to make sure that the inventor's particular idea is not too limited, the applicant should also include alternative ways in which the idea could be implemented (Durham, 2004). Bell's patent of March 7, 1876, included a single picture covering “. . . the method of, and apparatus for, transmitting vocal or other sounds telegraphically . . . by causing electrical undulations, similar in form to the vibrations of the air accompanying the said vocal or other sound (Casson, 1910: 37)." Contrary to patent application procedure, Bell's application did not include any alternative ways in which the aforementioned could be accomplished, yet it still claimed the entire realm of transmitting sounds telegraphically with the use of electricity.

A third requirement within the patent application process is that the inventors describe exactly what the patent "covers" (Durham, 2004: 19). One main requirement for patents is that they must be definite - specification shall "conclude with one or more claims particularly pointing out and distinctly claiming the subject matter which the applicant regards as his invention (Durham, 2004: 73)." However, the patent official who issued Bell's patent stated in court that he did not realize what the patent was claiming, and that if he "had believed it was for a talking telephone...[he] would have required a practical demonstration of its utility...as a talking machine (Warner, 1994: 12)." Thus, had Bell wanted to create a monopoly over the entire field of speaking telephones, he would be required to include that aim explicitly in his patent application. He never used the phrase, however, and it was arguably a stretch for his attorneys to claim that he had such rights over the entire telephonic industry. Thus, due to the lack of definition and absence of alternative options in his patent application, in conjunction with the broad, abstract idea that he was claiming, one could argue that Bell should not have won the "Dowd" case. 
Although it may have been a difficult climb, another legal remedy for Dolbear would have been to file suit against Bell on the grounds of "inequitable conduct," which consists of "misrepresentation made to the Patent Office, or a withholding of information (Durham, 2004: 127-128)." According to this approach, when Bell argued to Dolbear that Bell's version of the telephone had already been patented, Bell was knowingly taking someone else's ideas and using them as his own. ${ }^{9}$ In his book on patent law, Durham shows the drawings, specification, and claims within a mousetrap patent to explain this legal approach. There, he states that "[i]f a mousetrap did not incorporate one or more of the elements, it would fall outside the scope of what was claimed (Durham, 2004: 21)." Similarly, Dolbear's new invention that used static electricity may have produced a valid patent, as would have his permanent magnet telephone in 1877, had Bell not taken actions to prevent such a result. The question to observers, then, was: why did the patent office allow new telephone patents after Bell's, if they were to be overruled in court each time (Dolbear, 1963)?

Dolbear's company, in addition to many other telephone companies that had been defeated in court, appealed to have the matter solved by the U.S. Supreme Court. From 1883 to 1886, it began what would be referred to as "the telephone appeals," with its case being heard in October of 1886. After two years, the U.S. Supreme Court arrived at the same conclusion as prior courts, providing no new reasoning in its opinion. This came as a shock to Dolbear, given that in 1851 , in a parallel case occurred concerning the Morse code patent, the U.S. Supreme Court ruled that the operation of transmission was not patentable. Thus, it seemed logical for Dolbear to believe that the Court would find the same ruling to apply in his case, which was of nearly the exact same nature. ${ }^{10}$

When The Pan Electric Company, owned by several government officials, planned to bring the Bell case to the government's attention, it appeared as though a different outcome might result. Upon hearing this, The American Bell Telephone Company decided to talk personally with President Grover Cleveland (Dolbear, 1963). The company asked Cleveland to allow the hearing to take place in the Court of Massachusetts, where the previous Bell cases had been heard. However, the President did not accept their request. Instead, the government sought further investigation in order to determine if the claims, which stated that Bell had fraudulently been awarded his patents and that his "invention" was already public knowledge, were true. The matter was taken to Ohio's court, where it was ruled that the case needed to take place in Massachusetts (Dolbear, 1963).

Bell wanted all of its cases to be in the court of Massachusetts given that Judges Lowell and Gray, the magistrates who had ruled on Bell's previous court cases, owned, within their respective families, significant stock holdings in the Bell Telephone Company (Dolbear, 1963). After they decided in favor of Bell in court, the stock prices rose dramatically, from $\$ 200$ to $\$ 290$ per share. Lowell and Gray claimed they were oblivious to this fact. ${ }^{11}$ Additionally, the patent examiner proclaimed earlier that he had shown Bell the caveat that Gray had filed, only to later mysteriously retract the statement (Dolbear, 1963). This episode made it curious that between February 14 and March 7, a new claim appeared in Bell's patent application that was the same claim Gray had given in his caveat, which included using a wire that vibrated in liquid. It was this addition that allowed Bell to make the telephone useful (Dolbear, 1963). ${ }^{12}$ Believing that the case was the province of the U.S. Supreme Court, it was dismissed by Massachusetts in 1888. By this time, Bell's patent had expired, so the point was moot (Dolbear, 1963). The Bell Company had already created a monopoly in telephony.

\section{Concluding Remarks}

It was about that time - the late $1880 \mathrm{~s}$ - that the American public became concerned with the rise of monopolies, and the Bell cases were likely a large contributor to this concern. Many among the American public generally believed that monopolies and corporations were evil and "destructive to the principle of equal liberty (Letwin, 1965: 64)." After monopolies were attacked, so-called "trusts" began to form instead. However, they became known as the "latest version of the monopoly (Letwin, 1965: 70)." The situation of concern at the time was perhaps painted by the patent laws that had been created in the late $18^{\text {th }}$ century. They appeared to promote monopolies in exchange for what was hoped to be innovation. Judges had no clear line to differentiate between real and purported advancements. It may be the case that Dolbear, Gray and perhaps others, paid a price for the blurred lines within which the economic and legal systems of the time came together.

\section{Acknowledgements}

The authors thank an anonymous referee of this journal for several helpful comments on an earlier version, archivists at Ohio Wesleyan University for their assistance. The usual caveat applies.

\section{References}

Casson, H. N. (1910). The History of the Telephone. Chicago, IL: A.C. McClurg.

Devlin, A. (2009). The Stochastic Relationship between Patents and Antitrust. Journal of Competition Law and 
Economics, 5, 75-122. http://dx.doi.org/10.1093/joclec/nhn010

Dolbear, A. E. (1879). Researches in Telephony. Proceedings of the American Arts and Sciences, 16, 77-91.

Dolbear, I. S. (1963). Amos Emerson Dolbear: A Biography. New York: Dolbear.

Durham, A. L. (2004). Patent Law Essentials: A Concise Guide. Westport, CT: Praeger.

Gray, E. (1878). Experimental Researches in Electro-Harmonic Telegraphy and Telephony, 1867-1878. Appleton, MN: Appleton.

Krueger, A. O. (1974). The Political Economy of the Rent Seeking Society. American Economic Review, 64, 291-303.

Langton, W. C. (1933). Myths of Telephone History. Bell Telephone Quarterly, 12, 123-140.

Lemley, M. A. (2012). The Myth of the Sole Inventor. Michigan Law Review, 110, 709-760.

Letwin, W. (1965). Law and Economic Policy in America: the Evolution of the Sherman Antitrust Act. New York, NY: Random House.

Posner, R. A. (1975). The Social Costs of Monopoly and Regulation. Journal of Political Economy, 83, 807-827. http://dx.doi.org/10.1086/260357

Tullock, G. (1967). The Welfare Costs of Tariffs, Monopolies, and Theft. Western Economic Journal, 5, 224-232.

Warner, E. (1994). Telephone Etiquette. Ohio Wesleyan Magazine, 72, 8-12.

Watson, T. A. (1915). How Bell Invented the Telephone. Proceedings of the American Institute of Electrical Engineers, 34, 1,503-1,511. http://dx.doi.org/10.1109/PAIEE.1915.6590775

\section{Notes}

Note 1. The examiner in the patent office told Gray that he did not think his was a practical invention (Dolbear, 1963).

Note 2. Hubbard was rumored at the time to be a deceitful person (Dolbear, 1963).

Note 3. At this time, Western Union also held contracts with Thomas Edison and Elisha Gray (Dolbear, 1963).

Note 4. A Western Union director unknowingly told one of Dolbear's relatives, while laughing, that they "bought out Dolbear pretty cheap (Dolbear, 1963: 149)."

Note 5. Forbes was famous for his previous ventures with railroads and banks, through which he made a fortune (Dolbear, 1963).

Note 6. According to Dolbear (1963: 157), "[p]erhaps the court decided this case in such an off-hand manner because it did not appreciate the importance of the subject". The courts must not have anticipated the lengths that the Bell Company would rise to in order to obtain an enormous monopoly. With each company that came in Bell's way, a suit followed that crushed the competitors. Bell had "every right to the art of telephony, and every possible means of carrying on that art to the practical effect" (Dolbear, 1963: 160).

Note 7 These had not been rejected by the patent office because they were completely new inventions (Dolbear, 1963).

Note 8. Dolbear did not desire to patent the concept of transmission of speech in general, but only his new mechanism which could do so in a better manner (Dolbear, 1963).

Note 9. As described later in this study, other inventors employed this legal strategy, but failed.

Note 10. Interestingly, the Court also opined that the Bell Company had competed honorably (Dolbear, 1963).

Note 11. The Herald concluded that the Bell Company carried out "the most android conspiracy to deceive a court ever practiced in this country (Dolbear, 1963: 187)."

Note 12. It is believed that Bell and his lawyers may have replicated the application to include the new claim and, through their connections, they were able to replace the original application with the replication (Dolbear, 1963).

\section{Copyrights}

Copyright for this article is retained by the author(s), with first publication rights granted to the journal.

This is an open-access article distributed under the terms and conditions of the Creative Commons Attribution license (http://creativecommons.org/licenses/by/3.0/). 